\title{
LKPD Development Practicality on MEAs Based-Approach In Improving Mathematical Communication Ability Of Grade X Students
}

\author{
Putri Dewi Wardawati ${ }^{1}$, Irwan ${ }^{1}$, Jon Efendi ${ }^{1}$ \\ ${ }^{1}$ Universitas Negeri Padang, Padang, Indonesia, \\ *Corresponding author, e-mail: mahendraputridewi@yahoo.com
}

\begin{abstract}
The problems seen so far that at each level of tested questions requires different mathematical communication ability. Generally obtained the results of identification if the higher level of mathematics problems, the more the ability of mathematical communication explored student so that learning will become more meaningful. But Students work sheet used in the learning facilitate students' to develop their mathematical communication ability. One alternative to overcome this is by designing LKPD based on the Model Eliciting Activities (MEAs) approach. This study porpuse to test LKPD practicability based on MEAs approach that has been validated by mathematicians, language and education technology. From the result of questionnaire respond learners and teachers obtained practical value $87.4 \%$ and $88.24 \%$ with very practical criteria. LKPD MEAs according to the students have very practical use because it can improve the mathematical communication ability, the material in LKPD can be understood for the achievement of learning objectives.
\end{abstract}

Keywords: LKPD, Model Eliciting Activities, Practicality

How to Cite: Wardawati, P. D., Irwan, I., \& Efendi, J. (2018). LKPD Development Practicality on MEAs Based-Approach In Improving Mathematical Communication Ability Of Grade X Students. International Journal of Research in Counseling and Education, 2 (2) 83-87, https://doi.org/10.24036/0027za0002

\section{Introduction}

One element in education is mathematics. Mathematics is one field of study that has an important role in education. In addition, mathematics is also taught at all levels of education from elementary school to university. It is done with the purpose that students will have the ability to think mathematically such as in problem solving, mathematics reasoning, mathematics representation, mathematics connections, and mathematics communication (NCTM 2000). The result of mathematics education by Ruseffendi (2006) is that students are expected to have a creative, critical, scientific, honest, frugal, disciplined, diligent, humanitarian personality, have a sense of justice and are responsible for the welfare of the nation and state.

Math is given to all students without exception to be trained to think logically, analytically, systematically, and creatively. Mathematics is a symbolic language in which everyone who learns math is required to have the ability to communicate by using the symbol language. At the time of teaching and learning activities take place students usually get information about the mathematics concepts from teachers or readings, so that at that time there is transformation of information from the source to the students. Students will certainly respond based on their interpretation of the information. Problems will arise if the response given by the students is not in accordance with what is expected by the teacher. To overcome the occurrence of things like this, Students need to get used to learn to communicate the idea both orally and in writing.

Based on the observations in several schools in the city of Padang, namely SMA Negeri 3 Padang and SMA Negeri 12 Padang in september 2017, generally, the process of teaching and learning mathematics done by teachers to the students has a goal that students can understand and solve problems presented by teachers, but students are not often asked for clarity from the beginning when they get answers. As a result, students 
do not often communicate using the language of mathematics. The result of questionnaires from the students also shows the lack of mathematics communication ability of the students. The majority of students only learn mathematics when they are in school without doing a review or repetition when they are at home.

Factors that cause low mathematics communication ability of some Students are because of the approaches, models and learning methods used are not effective and do not support the improvement of the ability of mathematics communication, so the subject of mathematics becomes very difficult when faced with questions that require high communication skills. Similarly, it also happened to the type of the problem that has a relationship with everyday life that makes students confused and can not solve the problem. Students are not accustomed to working on questions related to everyday life, so that the ability of mathematics communication is low. Students can not communicate the results of learning, either at the time of reading or making graphs, tables or mathematics symbols as one form of communication ability mathematically. Mathematics communication can be motivated when students learn to solve mathematics problems, so students learn to find problems, investigate and solve problems through discussion between friends and the teacher from the data that students have gathered.

It is clarified by the teacher in the field of mathematics studies that in fact, it is hard for students to explain the lessons they have got. Based on the interview of the researcher with the mathematics teacher, it was revealed that the process of learning to teach mathematics is still going in the same direction, which is derived from the teacher to the students. Generally, the learning patterns at each meeting applied by the teacher are still conventional as they usually do the learning, that is by explaining the subject matters, giving examples of implementation, giving the exercises, and at the end of the teaching the teacher gives homework.

Viewed from the lesson plans used by the teacher, they have not referred to the standard of the learning process. The presentation of teaching materials has not been adapted to the learning model chosen in the lesson plan. This is due to the limitations of the teacher' s ability to make learning instruments in the form of lesson plans that can accommodate the needs of students. Generally, the teacher only imitates the existing lesson plans, or lesson plans exemplified by the supervisor. Meanwhile, the lesson plans that have been designed and copied by the teacher are not in accordance with the problems faced by the students that is the students who are passive in following the lesson, they are unable to communicate the ideas that they have, only one or two students who dare to ask or express opinions in one meeting.

One of the teaching materials that can enrich the knowledge and learning resources of the students is the students's work sheet (LKPD). LKPD is an additional resource that can be used by a teacher to improve mathematics ability and activities of the students. LKPD aims to facilitate students in the learning process. In addition, LKPD used is also less attractive and less supportive in improving the communication skills of students, so that it is hard for student to understand the problem in LKPD.

In relation to the LKPD, it is known that the students only use the Student Work Sheet (LKPD) created by MGMP or issued by the publisher. The students's worksheet (LKPD) is enough to help students in understanding the subject matters because it contains many excercises and tasks at home, but most of the problems are not presented to improve the mathematics communication ability of the students. In other words, the Student Work Sheet (LKPD) used has not been able to optimally and actively engage the Students to investigate and improve their mathematics communication skills. The LKPD criteria expected by the students are one which is colorful, has interesting images, and the problem varies. In addition, the preferred color to be the dominant color in LKPD is the blue color and the correct LKPD size is the usual LKPD size.

Mathematics learning in schools can still be optimized to improve the mathematics communication ability of the students. Appropriate learning approach will be able to improve student's communication. One of the solutions provided is through the use of the learning approach of Model Eliciting Activities (MEAs). MEAs is a mathematical learning approach for understanding, explaining, and communicating mathematics concepts contained in a study of problems through mathematics modeling. Furthermore, Chamberlin \& Moon (2008) revealed that the application of learning using the MEAs approach is done by using realistic learning scenarios.

The learning process using the MEAs approach begins with a realistic problem. This is expected to bring the interest for the students so that they can easily understand the problem because it is close to their daily life. Due to the easiness to understand the problems given, it is hoped that students can more easily translate the problem both into the form of images and mathematics symbols. Learning with this MEAs approach requires students to work in small groups consisting of 3-4 Students (Chamberlin: 2002). Through a group work, students have the opportunity to discuss, express ideas or opinions through words, and listen to ideas or opinions of friends. Thus, it is hoped that such learning will train the students to express their mathematics ideas through words. 
The main thing in learning MEAs is the activity of creating mathematics models. Chamberlin \& Moon (2008) said that the creation of a mathematics model requires a strong concept of understanding the problem so as to help students incarnate their minds. Mathematics models can be interpreted as a presentation of a situation or objects in a mathematical form. Through modeling students will be familiarized with the stages in modeling that are simplifying the problem, creating a mathematics model, transforming and solving problems with the model and interpreting the results. These stages are also connected to the steps to solve the problem on polya, so that the stages of the MEAs are expected to improve mathematics communication skills of students.

By considering the problems above, the Student Works Sheet (LKPD) should be developed in accordance with the needs and characters of the students and developed the mathematics ability of the students, especially the mathematics communication ability, one of them is the Student Working Sheet (LKPD). The principles of the MEAs approach will be applied in the preparation of lesson plans, LKPD and Test questions. Student Literacy Worksheet (LKPD) based on the Model Eliciting Activities Approach (MEAs) focuses more on students to communicate their mathematics concepts using accurate mathematics model representation based on culture or daily culture so that complex and abstract concepts become more concrete and easy to understand because it is presented in a context known by students.

The fun learning process of mathematics in the classroom is a hope for all students and teachers. Besides, the process of learning in the classroom is also expected to provide opportunities for students to participate actively in improving the ability to think, especially the ability of mathematics communication. This can be done by the teacher by designing an interesting learning activity and encouraging students in using their mindset through the development of learning tools such as RPP (Learning Implementation Plan) completed with LKPD. From the description, the researcher is interested to carry out a research in order to develop the learning instrument to improve the mathematics communication ability of high school students through MEAs with the title "LKPD Development Practicality On MEAs Based-Approach In Improving Mathematical Communication Ability Of Grade X Student".

\section{Method}

Research and Development is the type of research which was conducted. In this research and development, the products developed were mathematics lesson plans and LKPD using Model Eliciting Activities (MEAs) approach to improve the ability of mathematics communication ability of students, where this method would be applied by the researcher in grade X at SMA with the development model used was adapted from the Plomp model. This model was developed by Tjeerd Plomp which consists of 3 phases, namely: preliminary research (initial investigation phase) consisting of curriculum analysis, concept analysis, students' analysis, teachers' interview, and students' interview. Development or prototyping phase (development phase or prototype development) was done by formative evaluation. At last, the final assessment phase was a self evaluation and the expert review was referred as prototype 1, a one-to-one evaluation was referred as prototype 2 , a small group evaluation was referred as prototype 3 , and the result of a formative evaluation was referred as a prototype 4 . In the assessment phase, field testing was conducted in grade $\mathrm{X}$ at SMA Negeri 12 Padang to see the practicality.

Practicality is the level of achievement of learning instruments by conducting trials using LKPD-based MEAs approach that have been declared valid by the validator. Trial done was limited to students of grade $\mathrm{X}$ at SMA in the first Semester. LKPD was considered to be practical if students had no difficulty in learning. If it was not practical, then the revision was done until LKPD could be declared practical. The data were collected through interview sheets, teacher and students' response sheets, and mathematics communication ability test results of the students. The instrument was validated by three Mathematics experts, one Language expert, and one Technology Education expert at Padang State University (UNP).

Analysis of Practicality was performed to determine the implementation of the Model Eliciting Activities Approach (MEAs) based on the teachers' and students' response questionnaire scores. The steps taken to determine the practicality of Model Eliciting Activities (MEAs)- based approach were as follows:

Giving scores for each scale on the questionnaire of teacher and Students' response with the following criteria:

$$
\begin{aligned}
& \text { Score } 4 \text { = Strongly Agree }(\mathrm{SS}) \\
& \text { Score } 3 \text { = Agree }(\mathrm{S}) \\
& \text { Score } 2=\text { Disagree }(\mathrm{TS}) \\
& \text { Score } 1=\text { Strongly Disagree (STS) }
\end{aligned}
$$


Determining the average score of each item by the following formula:

$\overline{\mathrm{x}}=\frac{\sum_{\mathrm{i}=1}^{\mathrm{n}} \mathrm{x}_{\mathrm{i}}}{\mathrm{n}}$

With: $\bar{x}=$ the mean score of each item

$\mathrm{xi}=$ score given by the $\mathrm{i}$-th respondent

$\mathrm{n}=$ number of respondents (Walpole, 1992: 23)

Determining the value of practicality by using the formula:

$\mathrm{P}=\mathrm{R} / \mathrm{SM} \times 100 \%$

Information:

$\mathrm{P} \quad=$ Practical Value

$\mathrm{R} \quad=$ Score obtained

SM = Maximum score (Purwanto, 2012)

The category of practice is determined by the following achievement criteria::

Table 1. Kriteria Practical Criteria

\begin{tabular}{|c|l|}
\hline $\begin{array}{c}\text { Achievement } \\
\text { Rate (\%) }\end{array}$ & Range Presentase \\
\hline $85-100$ & Very Practical \\
\hline $75-84$ & Practical \\
\hline $60-74$ & Quite Practical \\
\hline $55-59$ & Less Practical \\
\hline $0-54$ & Not Practical \\
\hline
\end{tabular}

Source: (Purwanto, 2012)

Based on the criteria above, the Model Eliciting Activities (MEAs) approach -based LKPD is considered to be practical if the practicality value is $\geq 60 \%$.

\section{Results and Discussion}

1. Research result

The instruments used to collect practical data were as follows.

a. Questionnaire of Students Response

Questionnaire of Students' responses was used to get the students' response to learning instruments developed. This instrument was filled by the students after following the learning process during the field test. Questionnaire of Students' responses consisted of aspects of attractiveness, process of use, ease of use, and time efficiency. Based on the results of Questionnaire of Students' responses followed by 34 students, it was obtained that the average practicality values of each aspect were $87.87 \% ; 84.74 \%$; $85.66 \%$; $78.68 \%$; which were in the practical and very practical category with an average of $87.38 \%$. Thus, it can be concluded that the Model Eliciting Activities (MEAs)-based LKPD approach was very practical according to the students' responses.

\section{b. Questionnaire of Teachers Response}

Questionnaire of Teachers Response was used to get teachers' response to the learning intrument developed. This instrument was filled by the teachers after the learning process during the field test. Questionnaire of Teachers Response consisted of aspects of attractiveness, use process, ease of use, and time efficiency. Questionnaire of practicality was given to the mathematics teacher of grade X of SMAN 12 Padang after all RPP and LKPD were conducted in the learning process. Based on the results of the questionnaire analysis of the teachers' response, it was obtained that the percentage for each aspect was ranged from 75\% to $100 \%$, for the practical and very practical category was an average of $88.24 \%$. Thus, it can be concluded that the RPP and LKPD used are practical. 


\section{Discussion}

In assessing the practicality in this tool, then data were collected through observation of learning implementation and questionnaires practicality filled by students and teachers. The learning implementation using Model Eliciting Activities (MEAs) approach-based instrument indicated that the learning process created a class situation that encouraged students to ask questions to each other, answer and express opinions, and the interaction between students.

The learning process with the Model Eliciting Activities (MEAs) -based instrument could foster the motivation and enthusiasm of students in learning through a variety of fun activities. This activity indirectly encouraged the active participation of students during the learning process. In addition, learning using Model Eliciting Activities approach (MEAs)- based instrument could stimulate students very well in learning and could develop independence and creativity in understanding LKPD and solving problems. Similarly, interviews with students and teachers indicated that LKPD used was clear and could help students to understand the concepts so that they could understand the lesson well.

During the implementation of learning by using Model Eliciting Activities (MEAs) approach- based instrument, in general, the time provided was sufficient. Although some students thought differently and not all the exercises and discussion of problems contained in LKPD were well completed. This was because the ability of the students themselves was different so that it consumed a lot of time in completing an activity. Some students found it difficult to present their ideas in communicating knowledge and solving problems, thus asking teachers a lot. Students were accustomed to get information from the teacher completely without having to think to find the information itself. To solve this problem, during the teaching process the teacher was tasked with helping students by directing them into thinking so they could come up with ideas to understand the material independently.

The use of learning tools could help teachers in the learning process. For students, the use of learning instruments could also make it easier for them to understand the lessons and solve problems related to their daily lives because students could understand the learning materials based on LKPD that they did well. Thus, if students are faced with problems related to the problems of everyday life, they are not awkward anymore, and they can do well and thoroughly.

\section{Conclusion}

Based on the research that has been done, it can be concluded that this research is a development research that produces learning instruments based on the Model Eliciting Activities (MEAs) approach in the form of LKPD with practical categories from the aspects of implementation, ease, and the time required. This can be seen from the students' questionnaire of practicality and teacher's questionnaire of practicality and the observation results of learning implementation.

\section{References}

Hamdani. 2010. Strategi Belajar Mengajar. Bandung: CV. Pustaka setia.

Hulukati, E. (2005). Mengembangkan Kemampuan Komunikasi dan Pemecahan Masalah Matematik Siswa SMP melalui Model Pembelajaran Generatif. Disertasi. Program Pascasarjana UPI. Tidak Diterbitkan

Irwan dan Nurlaili. 2016. Pengembangan Perangkat Pembelajaran Berbasis Model Eleciting Activities (MEAs) untuk Meningkatkan Kemampuan Pemecahhan Masalah Pada Pembelajaran Matematika Kelas VIII SMP. Padang: Jurusan Matematika FMIPA UNP. Laporan Penelitian tidak diterbitkan.

NCTM. 2000. Principles and Standards for School Mathematics. Reston, VA: NCTM

Plomp, Tjeerd. 2013. An Introduction to Educational Design Research :SLO - Netherlands Institute for Curriculum Development.

Peraturan Menteri Pendidikan Nasional Nomor 58 Tahun 2014 tentang Kurikulum SMP. 2013. Jakarta: Kemendikbud.

Purwanto, Ngalim. 2012. Prinsi-prinsip dan Teknik Evaluasi Pengajaran. Bandung: Remaja Rosdakarya 